\title{
非対称振動流場での地形侵食速度に関する 実験的研究

\author{
EXPERIMENTAL STUDY ON THE LOCAL EROSION VELOCITY \\ DUE TO ASYMMETRY OSCILLATORY FLOW
}

\author{
山下 俊彦 ${ }^{1}$ - 金子 寛次 ${ }^{2}$ - 新山 雅紀 $^{3}$ - 永田 晋一郎 ${ }^{4}$ \\ Toshihiko YAMASHITA, Hirotugu KANEKO, Masaki NIIYAMA, Shinichiro NAGATA \\ ${ }^{1}$ 正会員 工博 北海道大学大学院助教授 工学研究科 （ $\overline{\mathrm{T}} 060-8628$ 札幌市北区北 13 条西 8 丁目） \\ ${ }^{2}$ 正会員 工修 北海道（广060-8588 札幌市中央区北 3 条西 7 丁目） \\ 3 学生会員 工学 北海道大学大学院 工学研究科 (厂 060-8628 札幌市北区北 13 条西 8 丁目) \\ 4 農学 北海道開発局 開発土木研究所（广 062-8602 札幌市豊平区平岸 1 条 3 丁目）
}

\begin{abstract}
Burrowing bivalves such as surf clams (Pseudocardium sybillae) that inhabit open sandy beaches are an important fishery resource. The main reason for the decrease in the number of bivalves is due to high waves, and the release of bivalves from the seabed into the water is thought to be the first phase in the mortality process of bivalves. Local erosion and accumulation velocities during sand ripplc formation caused by the asymmetry oscillatory flow are experimentally studied.The intensity of bed deformation speed and maximum erosion velocity due to asymmetry oscillatry flow are estimated from the results due to oscillatry flow, taking into account the effect of asymmetry on Shields number.
\end{abstract}

Key words : Asymmetry flow,sand ripple, bed deformation speed, erosion velocity

\section{1. 研究目的}

北日本沿岸の開放性砂浜域には、ウバガイ、エゾバ カガイ等の潜砂性二枚貝が生息している。これらはホ タテガイに次ぐ重要な貝類の水産資源であるが、稚貝 段階での著しい減耗が增殖の障害となっている。この 原因として冬季の高波浪が指摘されている。また、港 の建設後にその静穏域に稚貝の増加例が報告されるな ど、海岸構造物と関倸の深い生物でもある。ウバガイ 等の潜砂性二枚貝は、高波浪により砂中から水中に放 出され、流れにより振動させられたり、生存不可能な 場所へ運ばれたりして減耗へ至ることが知られてい る。著者らの研究により、ウバガイの放出限界 (貝が砂 中から水中へと放出される限界の地形侵食速度) は、 地形侵食速度 Ve と貝の潜砂速度 Vbの比で決定され、 $\mathrm{Ve} / \mathrm{Vb}$ は約 1.0 であること、また貝の潜砂速度は殼長 が小さいほど、水温が低いほど小さくなることが定量 的に明らかにされている。一方、放出限界に関係する 波による瞬間的に大きな地形侵食速度については、松 岡・山下 $(1995)^{1)}$ 、山下・木下 $(1996)^{2)}$ 、山下ら (1997)
${ }^{3)}$ の振動流場での研究しか行われておらず、有限振幅 波を対象とした研究はなされていない。そこで本研究 では、任意波形振動流装置を用い、非対称振動流場で の砂漣形成時の地形侵食速度を系統的実験より把握 し、地形侵食速度への流れの非対称性の効果を明らか にする。

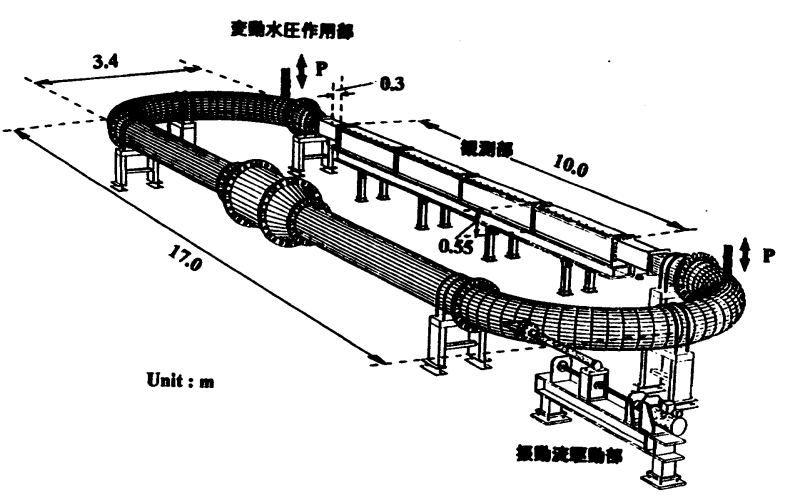

目一-1 任意波形振動流装置 


\section{2. 研究内容}

実験は、図一1に示す任意波形振動流装置を用いて、 非対称振動流速 $\mathrm{u}$ として図一 2 に示す $\mathrm{u}=\mathrm{Um}(\sin 2$ $\pi \mathrm{t} / \mathrm{T}-\mathrm{A} \cos 4 \pi \mathrm{t} / \mathrm{T})$ で行なった。実験条件は、周 期 $\mathrm{T}=3.5 、 6 、 10$ 秒、 $\mathrm{Um}=40 \mathrm{~cm} / \mathrm{s}$ 、水温 $15^{\circ} \mathrm{C}$ 、非 対称振動流の効果を調べるため、 $\mathrm{A}=0 、 0.1 、 0.2$ と した。底面には粒径 $\mathrm{d}=0.3 \mathrm{~mm}$ の硅砂を敷いた。実験 I は、対称振動流 $(A=0)$ で砂漣を形成した後、次に 非対称振動流として $\mathrm{A}=0.1 、 0.2$ をそれぞれ 1 時間 作用させる (以下Up と表示)もので、実験 II は非対称 振動流 $(\mathrm{A}=0.2)$ で平坦床から砂漣をつくり、 $\mathrm{A}=$ $0.1 、 0$ と振動流を作用させた (Down) ものである。最 大侵食速度Vemとして、砂漣一波長内での各地点にお ける砂漣形成過程での最大侵食速度を求めた。地形変 化強度 Vは一定時間平均の各地点での地形変化速度で ある。地形変化強度 Vは常時の生物への地形変化の影 響度、最大侵食速度Vemは激浪時の生物の減耗(生物は Vemが生物自身の潜砂速度を越えると砂中から水中へ と放出され減耗の第一段階になる)の指標と考えられ る。また貝は殻長の半分程度が砂上に出されると貝全 体が砂上に出されやすくなることから、貝の放出に影 響する侵食速度として、殼長の半分の距離の侵食に対 する平均侵食速度をとった。すなわち殸長 L $20 \mathrm{~mm} 、 30 \mathrm{~mm}$ の 3 種類の貝を想定した場合、各々侵食 深さは、 $5 \mathrm{~mm} 、 10 \mathrm{~mm} 、 15 \mathrm{~mm}$ となり、これらの距離の侵 食に対する平均侵食速度の砂漣形成過程の最大の地形 侵食速度を各場所ごとに求めた。

\section{3. 主要な結詥}

\section{（1）地形の時系列変化}

図一 3 に平坦床から $\mathrm{A}=0.2$ の非対称振動流を作用

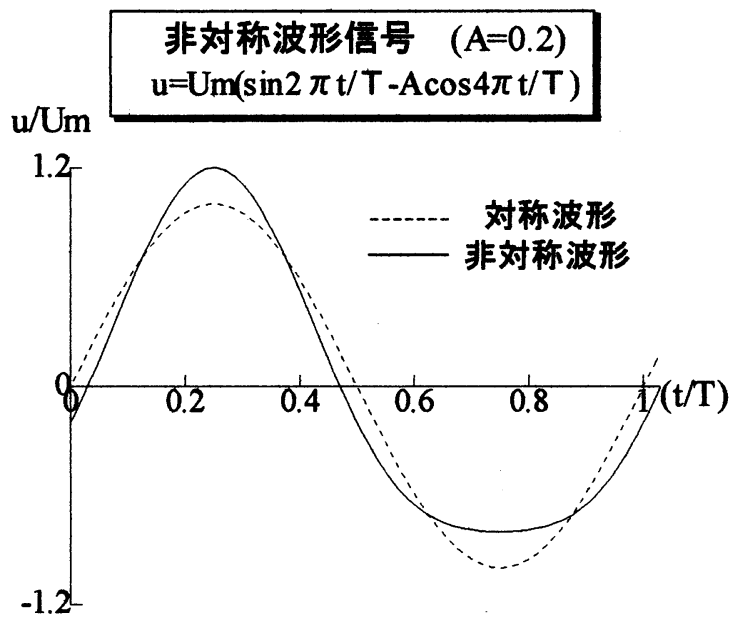

图-2 非対称波形信号 $(\mathrm{A}=0.2)$

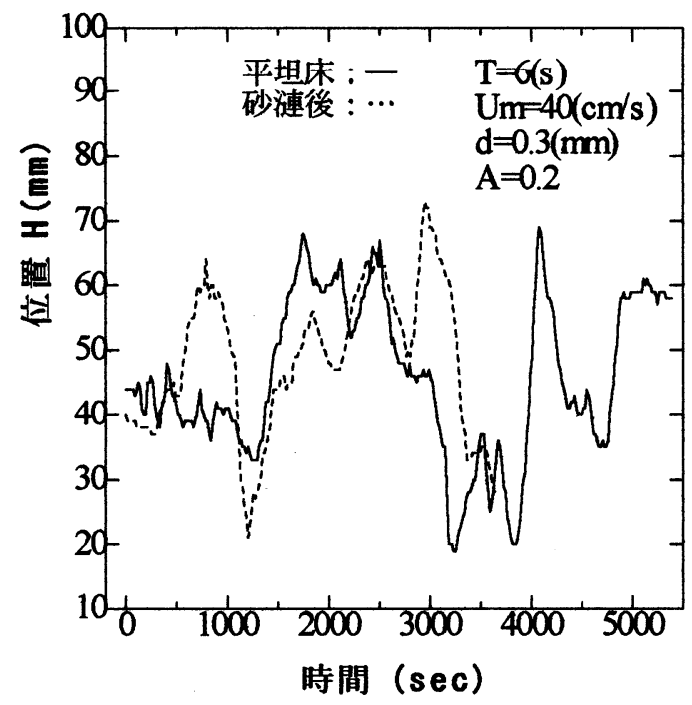

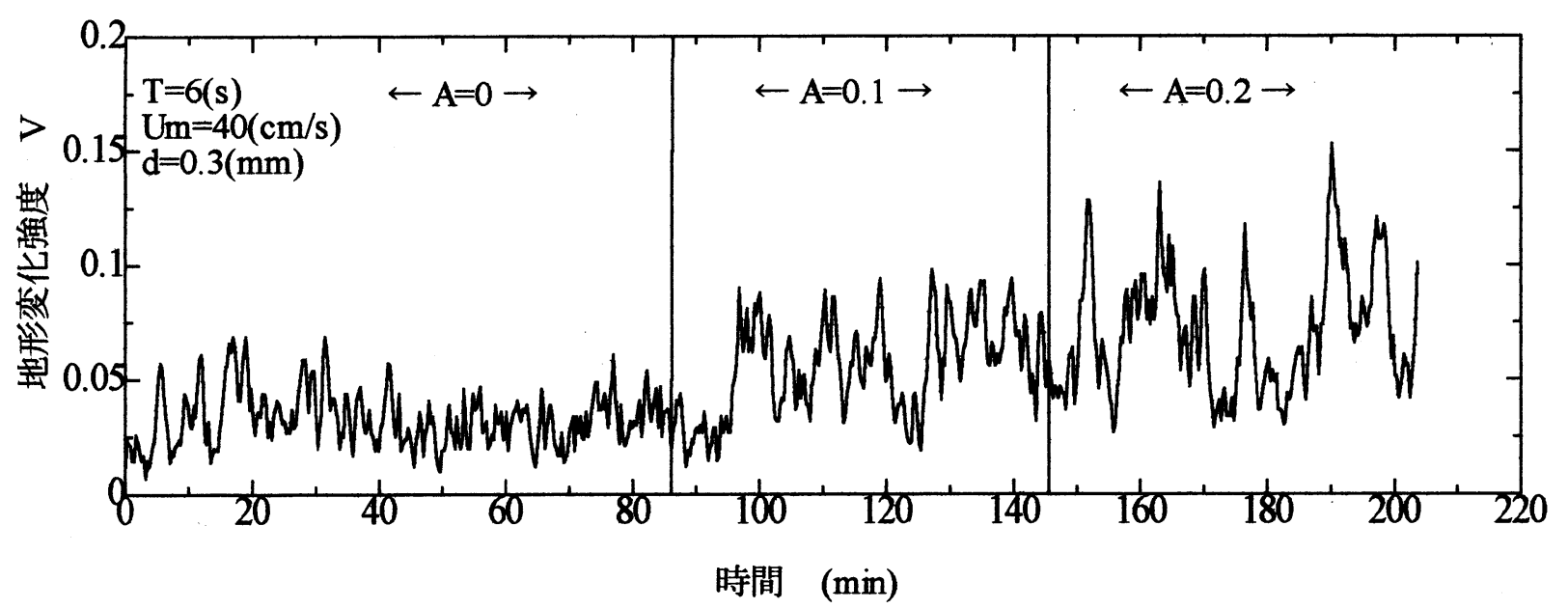

图-4 地形変化強度Vの時系列変化 $(\mathrm{A}=0$ から $)$ 


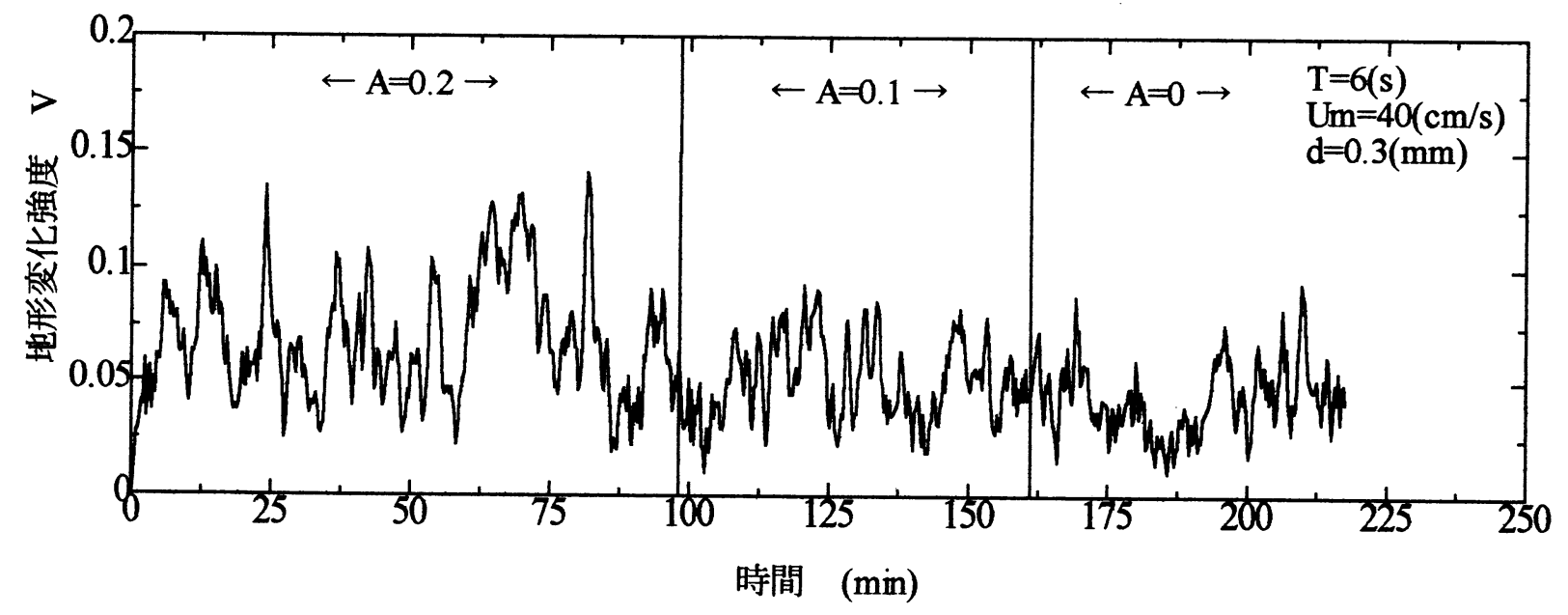

图－5 地形変化強度Vの時系列変化 $\quad(A=0.2$ 加 $)$

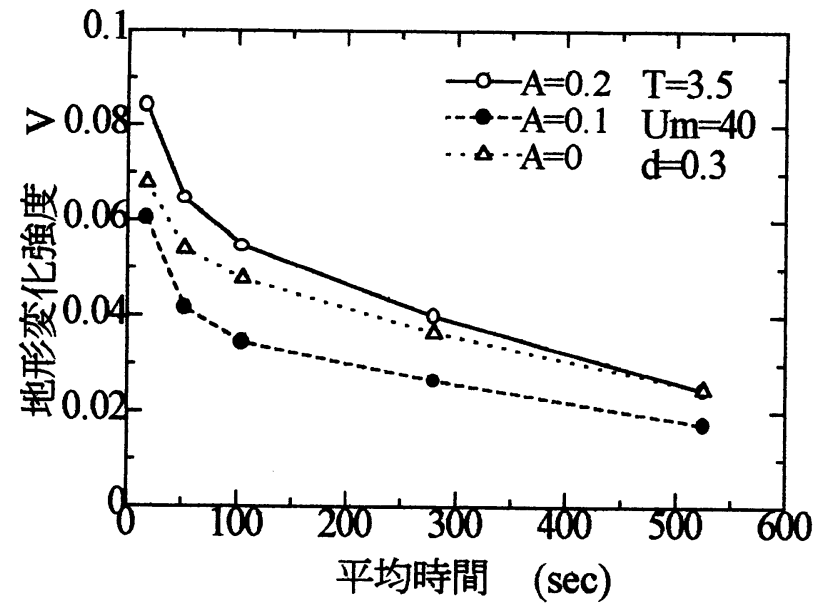

图－6 地形変化強度と平均時間 $(T=3.5)$

させた場合と、一度 $\mathrm{A}=0.1$ の振動流で砂漣を形成し た後 $\mathrm{A}=0.2$ の振動流を作用させた場合の地形変化の 時系列の一例を示す。この図よりどちらの場合も、10 〜2000秒程度の広い範囲の周期を持った地形変動が みられ、砂軏が安定するまでは、砂漣の合体、消滅を 複雑に絽り返していることが分かる。

\section{（2）地形变化強度の時系列变化}

図-4、5に一分平均の地形変化強度 $\mathrm{V}$ の時系列変化 を示す。これより、Vは実験開始初期の段階で少し小 さいが、その後も変動はあるものの、どちらの図にお いても $\mathrm{A}=0.2$ で大きく、 $\mathrm{A}=0$ では小さめの值となっ ており、その值はほぼ一定していることがわかる。地 形変化強度 Vは 20 秒、 1 分、 2 分、 5 分の時間平均地 形変化速さを砂漣一波長分平均して求めた。この時の 地形変化強度の変化を図一6、7、8に示す。これより 雨量強度と同様、平均時間間隔の増加とともに地形変 化強度が減少していくことが定量的にわかる。

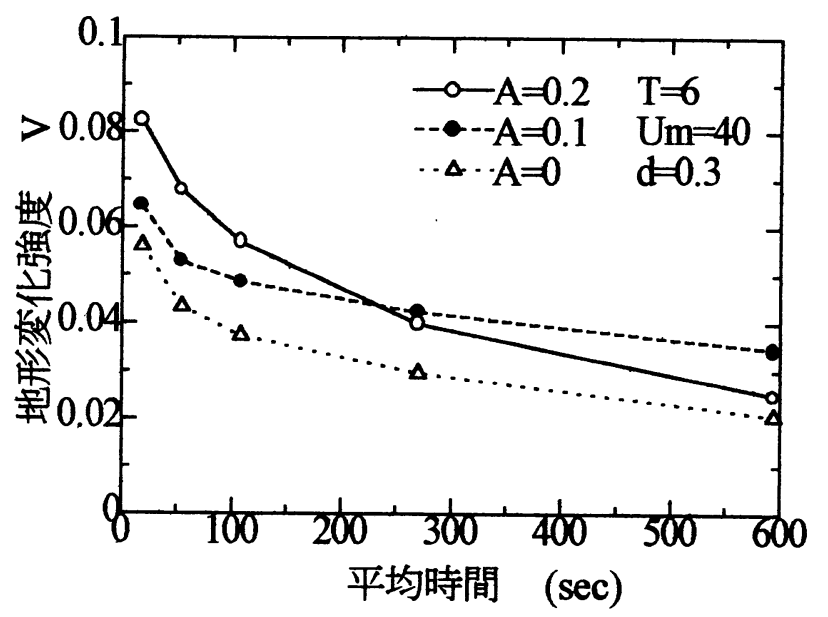

图-7 地形変化強度と平均時間 $\quad(T=6)$

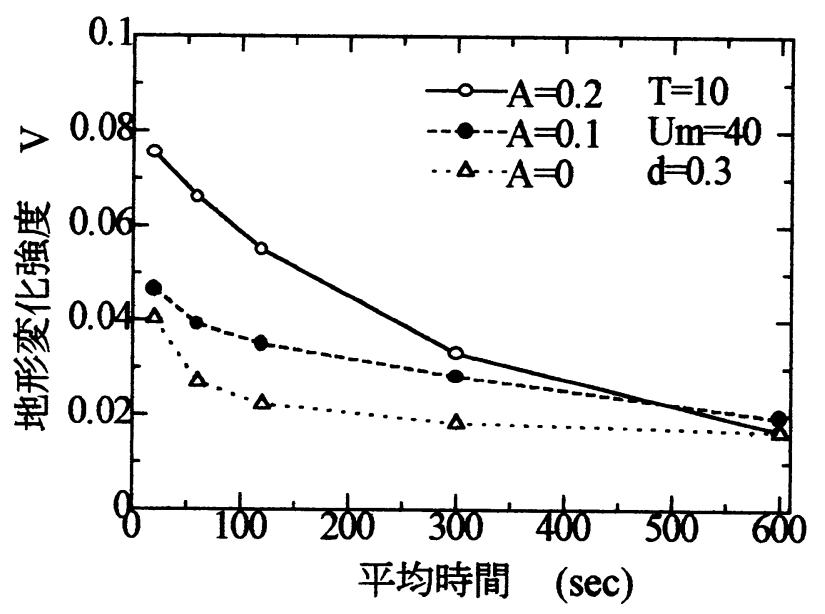

图-8 地形変化強度と平均時間 $\quad(\mathrm{T}=10)$

\section{（3）地形变化强度 $V$ と $\Psi$}

図一9は地形変化強度 $\mathrm{V}$ とシールズ数 $\Psi$ の関俰を示 したものである。本実験の非対称振動流の場合、半周 


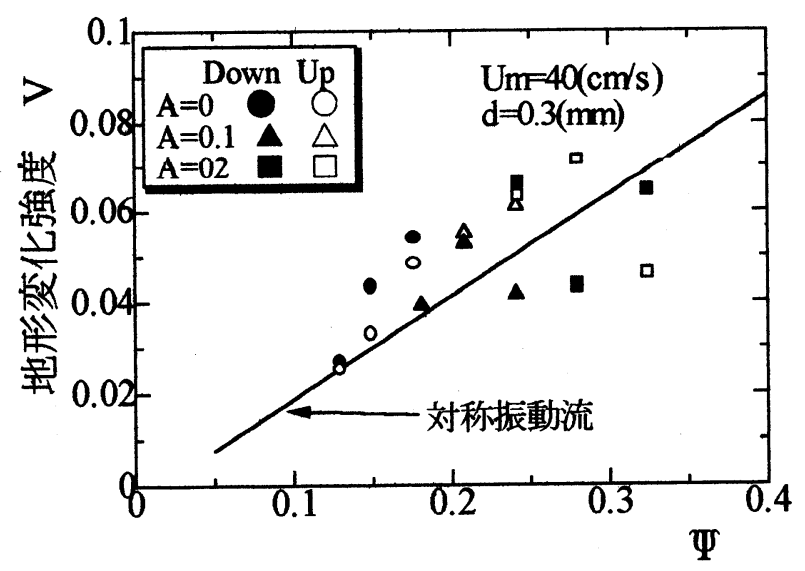

图－9 地形変化強度 $\mathrm{V}$ と $\Psi$

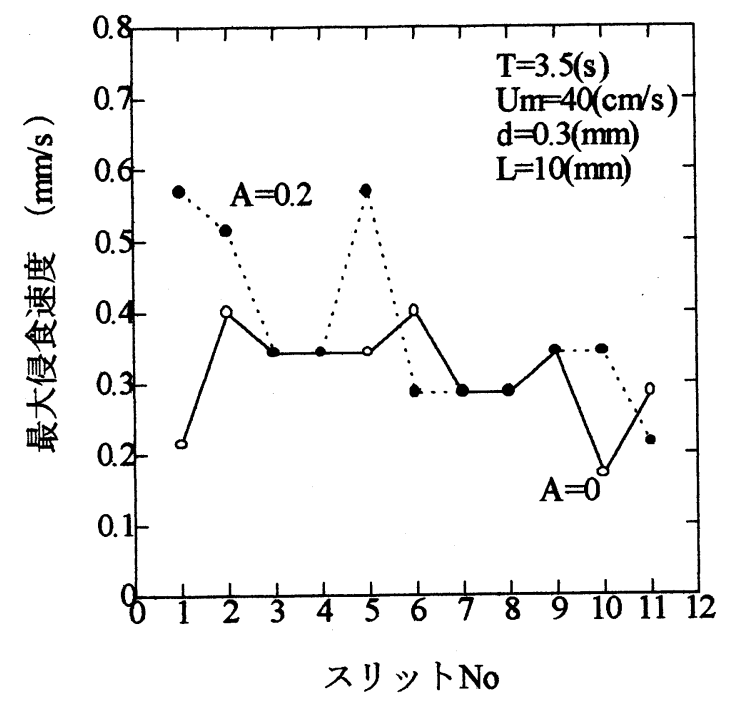

图-10 各地点での最大侵食速度 $\quad(T=3.5)$

期移動距離は変らないため底面摩擦抵抗は変らないと 考え、最大流速 $U$ max $=(1+A) U m$ として求めた。また、 図中の直線は対称振動流で得られた值である。Up と Downでは大きな違いはみられず、前述の様なシールズ 数を採用することで、対称振動流の結果とほぼ一致す ることが確かめられた。

\section{(4) 平坦床からの各地点での最大侵食速度}

図一 $10 、 11 、 12$ は平坦床から対称振動流 $(\mathrm{A}=0)$ を 作用させた場合と非対称振動流 $(\mathrm{A}=0.2)$ を作用させ た場合について、それぞれ図ー 10 は周期 $\mathrm{T}=3.5$ 秒、 図一 11 は 6 秒、図一 12 は 10 秒で各条件についてまと めたものである。図中スリット1〜11が約砂漣一波長 に相当する。これらの図より、それぞれの周期で同じ 流速、硅砂粒径でも半坦床から砂漣を形成させる場合 には $\mathrm{A}=0$ より 0.2 の方がより大きな地形侵食速度が 発生していることが分かった。

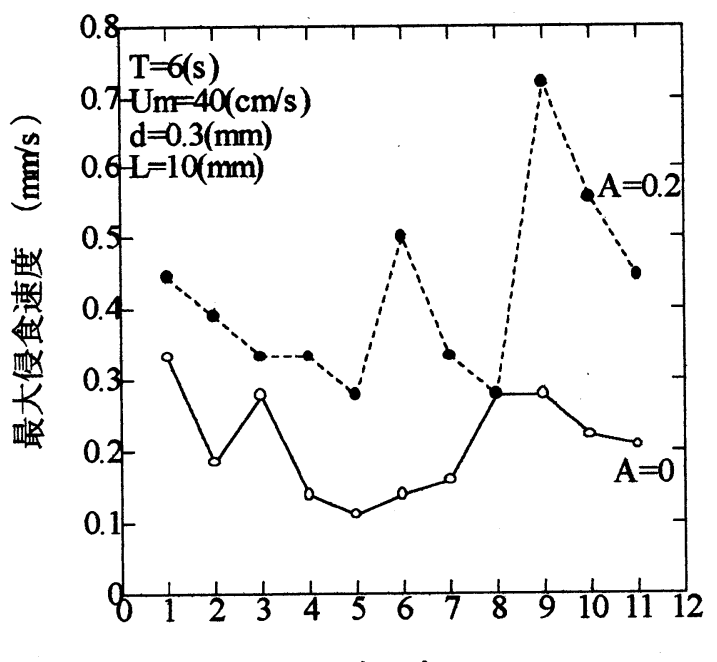

スリットNo

图-11 各地点での最大侵食速度 $\quad(T=6)$

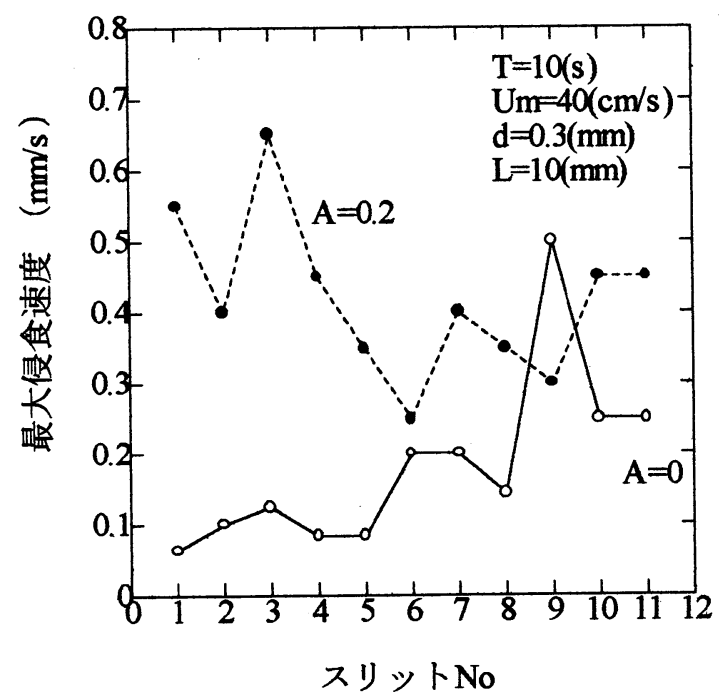

图-12 各地点での最大侵食速度 $\quad(\mathrm{T}=10)$

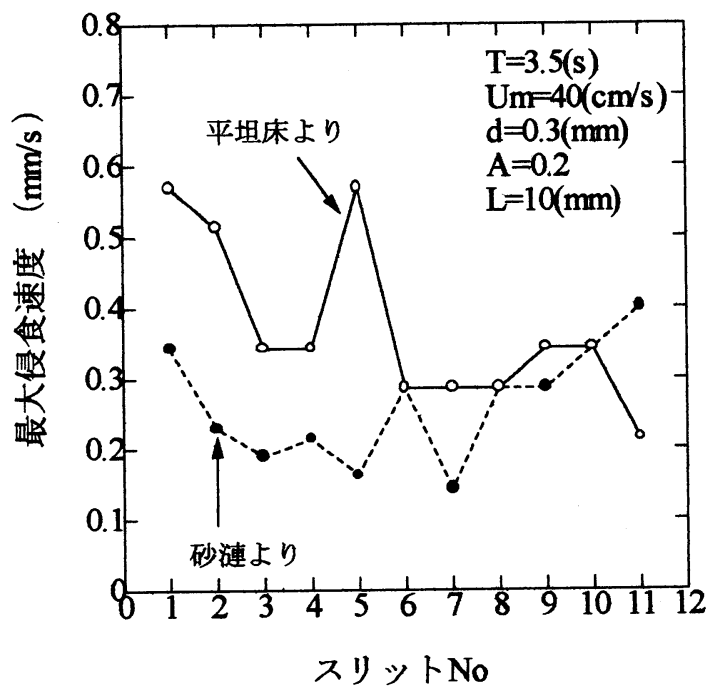

图-13 各地点での最大侵食速度 $\quad(T=3.5)$ 


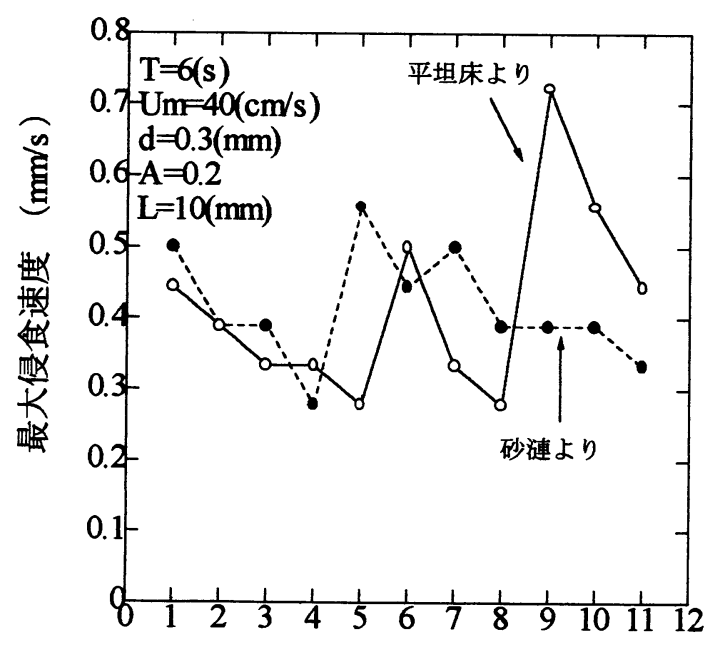

スリットNo

図-14 各地点での最大侵食速度 $\quad(T=6)$

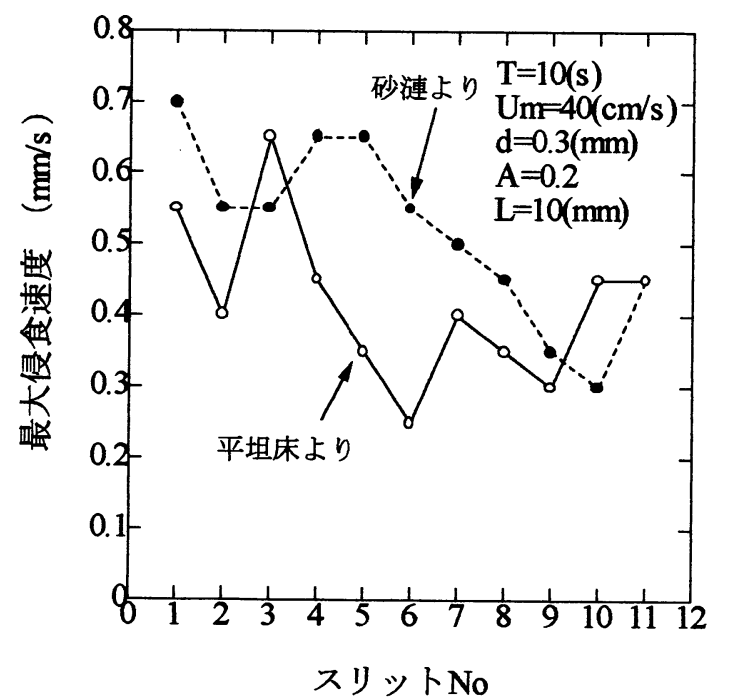

图-15 各地点での最大侵食速度 $\quad(T=10)$

\section{（5）杪漣形成後の各地点での最大侵食速度}

図-13、14、15 に平坦床から非対称振動流 $(A=$ 0.2）を作用させた場合と、一度 $\mathrm{A}=0.1$ の振動流で砂 漣を形成した後、非対称振動流 $(A=0.2)$ を作用させ た場合の各地点での最大侵食速度の一例を示す。図一 13 は周期 $\mathrm{T}=3.5$ 秒、 $\mathrm{A}=0.2$ の場合で、図一 14 は $\mathrm{T}=6$ 秒、図一 15 は $\mathrm{T}=10$ 秒について各々の条件に ついてまとめたものである。これらより、どの条件で も平坦床から振動流を作用させた場合と砂漣形成後に 振動流を作用させた場合とでそれほど大きな違いはみ られなかった。これは、砂漣が形成される際の大きな 地形侵食速度は砂漣の合体、消隇等で発生するため、 初期地形はあまり影響がないものと考えられる。

\section{（6）最大侵食速度の発生確率}

図一 16、17、18 は図ー10、11、12 等を基に砂漣一

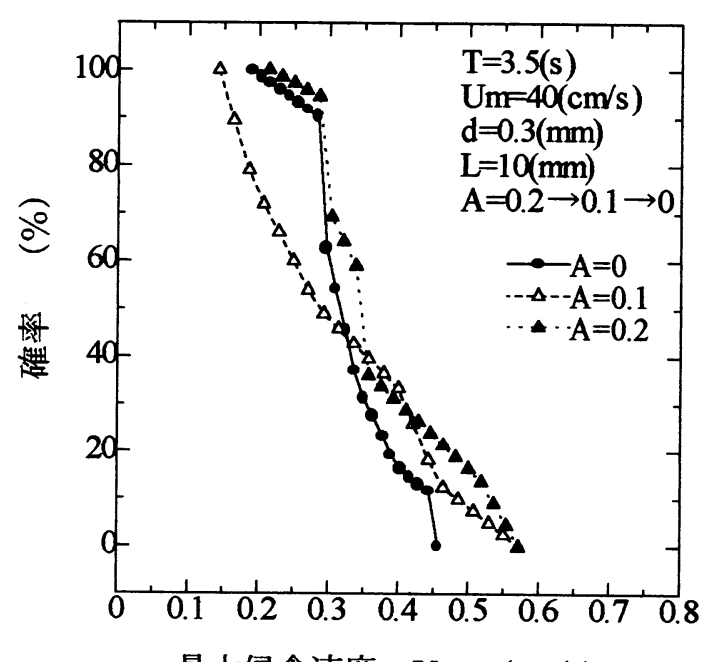

最大侵食速度 $\operatorname{Vemax}(\mathrm{mm} / \mathrm{s})$

图-16 最大侵食速度の発生確率 $\quad(\mathrm{T}=3.5)$

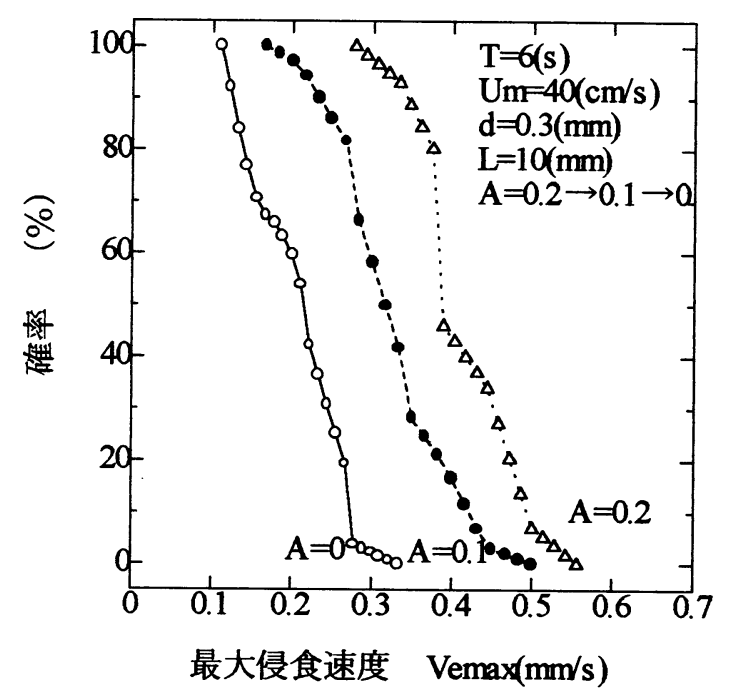

图-17 最大侵食速度の発生確率 $\quad(T=6)$

波長内での最大侵食速度の場所的発生確率をもとめた ものである。図一 16 は $\mathrm{T}=3.5$ 秒、図一 17 は $\mathrm{T}=6$ 秒、図一 18 は $\mathrm{T}=10$ 秒についてそれぞれの条件でま とめたものである。これらの図より、非対称性が強い ほど、大きな地形侵食速度が発生する確率が高くなる こと $(\mathrm{T}=6 、 \mathrm{Um}=40 \mathrm{~cm} / \mathrm{s} 、 \mathrm{~d}=0.3 \mathrm{~mm} 、 \mathrm{~A}=0.2$ の 場合の最大侵食速度は $\mathrm{A}=00$ 同条件の約2倍)が定量 的にわかる。これは、 $\mathrm{A}=0.2$ の万が最大流速が大さ いことと、砂漣が移動することによるものと考えられ る。

\section{(7) Ve50とシールズ数}

図-18中の直線、点線はそれぞれのデータを直線近 似したものである。最大侵食速度の発生確率を $50 \%$ 発 生確率の地形侵食速度Ve50 とその傾き $\mathrm{K}$ で代表させ る。Ve50と (3) で用いた各非対称振動流のシールズ数 


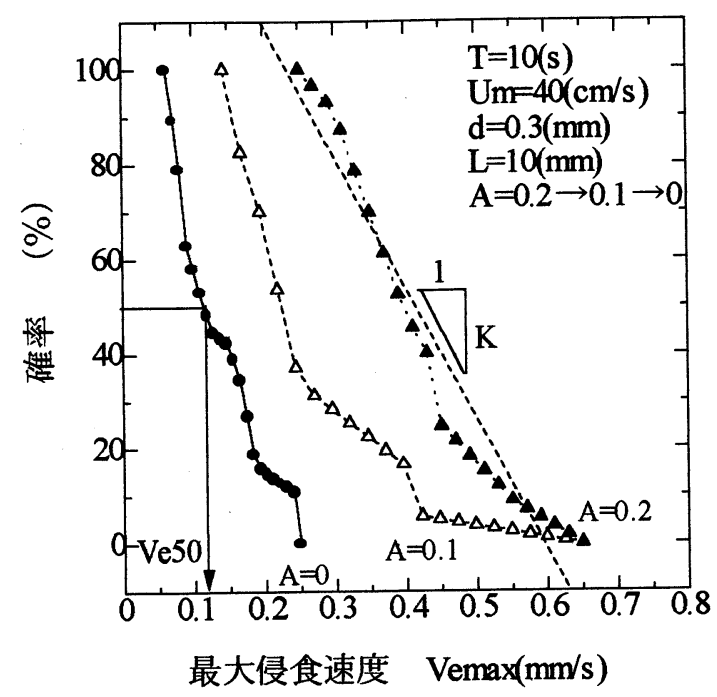

图-18 最大侵食速度の発生確率 $\quad(\mathrm{T}=10)$

との関係を示したものが図ー19である。これより若干 のばらつきはあるものの、非対称性の増加(シールズ 数の増加)に伴ってVe50も直線的に増加していること が定量的にわかる。図中の直線は (3) と同様、対称振動 流での值である。ここでもUp と Downでは大きな違い はみられず、非対称性を考慮したシールズ数を採用す ることで、Ve50も対称振動流の結果とほぼ一致するこ とが確かめられた。

\section{（8）最大侵食速度の頃き $\mathrm{K} * \mathrm{Ve} 50$}

$\mathrm{K} * \mathrm{Ve} 50$ とシールズ数の関係を示したものが図一 20 である。この図より $\mathrm{K} * \mathrm{Ve} 50$ の值は、Up, Down で 大きな違いはみられず、対称振動流での值-1.0にほぼ 一致することが確かめられた。

\section{参考文献}

1）山下俊彦・和田 彰・松岡 学・谷野賢二 - 明田 定満: 振動流場での二枚貝の挙動に関する実験的研 究、海岸工学論文集、第42巻 (1)、pp. 506-510, 1995

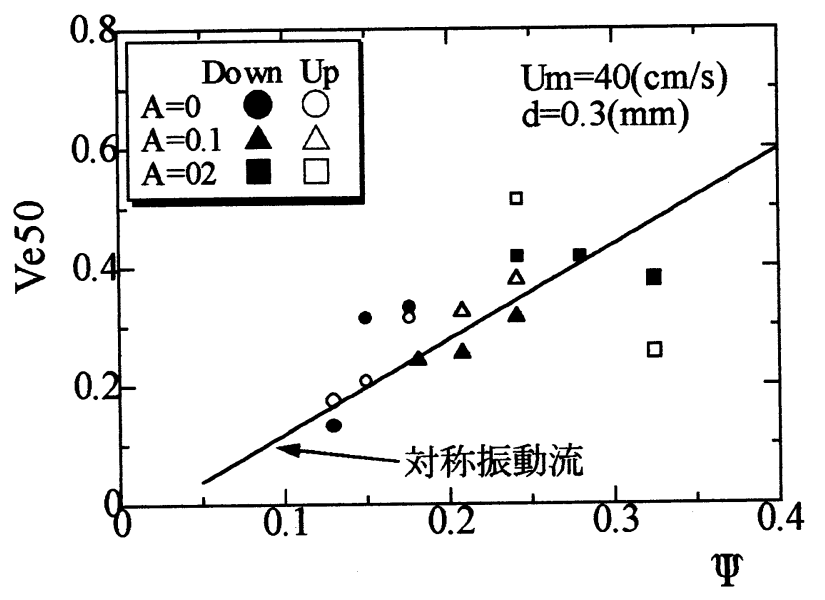

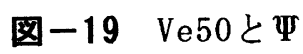

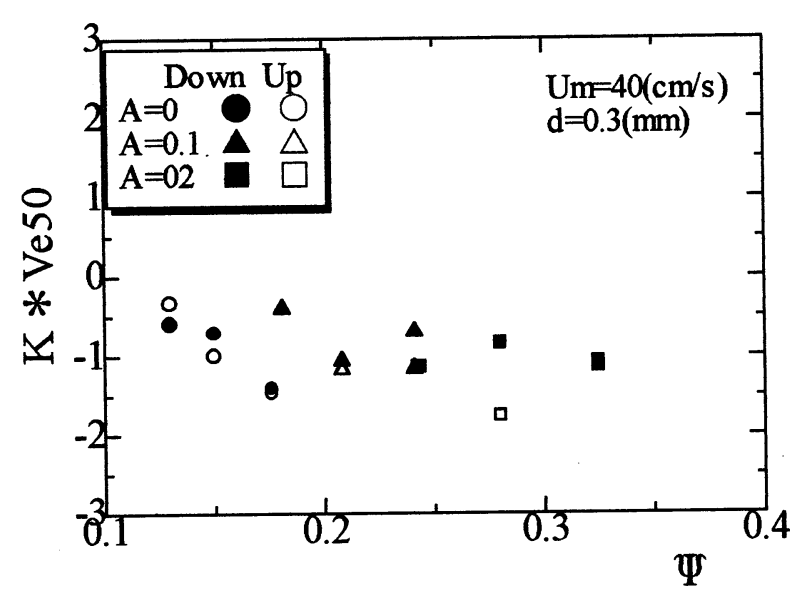

图一20 $\mathrm{K} * \operatorname{Ve} 50$ と $\Psi$

2）山下俊彦・木下大也・和田彰・明田定満 - 谷野賢 二: 振動流場での二枚貝の放出限界と潜砂限界、海洋 開発論文集、Vol. 12、pp. 467-472, 1996

3）山下俊彦·金子寛次 - 和田彰・山本明 - 北原繁志 谷野賢二:砂漣形成時の地形侵食速度と潜砂性二枚貝 の放出確率、海岸工学論文集、第 44 巻 (1)、pp. 701705,1997

(1999. 4. 19受付) 